\title{
NURTURING ABSTRACTIONS OF THE NATION IN RELIGIO-CULTURAL IDENTITY ASSERTIONS AND SPACES OF GENEROSITY IN THE SUFI DARGHAS OF KARNATAKA
}

\author{
Amitha Santiago \\ Bishop Cotton Women's Christian College, Bangalore \\ <amithasantiago@gmail.com>
}

'But why do nations celebrate their hoariness, not their astonishing youth?'1 Benedict Anderson

Socio-political reality is often brought into being through performative acts. To say that religio-cultural identity stakes its claim on the socio-political through performative utterances is to also state that socio-political realities appear as effects of articulated ideology. It has been well acknowledged that socio-political ideology presents itself as if it were offering some 'deeper, extra political truths' of being and becoming that are constant. This brings forth a believing community, which functions as a stabilizing occurrence for these 'deeper, extra political truths' of being and becoming. Assertions of essential religio-cultural identity constitute one

1 Bhabha, K Homi. in Location of Culture. Pg 141 such discursive practice that brings into effect communities that nurture binarizing abstractions such as what it is to be 'Indian', the idea of who is a 'Hindu' and the notion of nationalism that elects an umbilical connect to the Hindu Vedic lineage.

It is to understand the processes that are involved in the crafting of these extra political truths of being and becoming, to examine whether these truths are in fact extra political, and to come to an understanding of how he believing communities which are effected preserve an abstraction of pure national identity that this study engages shared sacred spaces that have been claimed by Hindu right-wing 
assertionists in India. In such an effort, the juxtaposition-ality of these shared sacred spaces of grace that harbor a substratum of generosity and sharing, marks the essentializing procedures of right wingers and their aggressive mining for a pure Indianness. Except that the ground they mine is amorphous.

Located as it is within the terrain of religio-cultural identity studies, this study inevitably focuses on the contractual laboring of the historical and the political in India. This alliance points to processes that sustain the articulatory systems that liaison with identity politics. There is in India, reminiscent of decolonization times, a deafening clamor to describe national identity in terms of a pure, religiocultural essence that is to deliver a historically constituted national identity. In the context of the growing polemic on the issue of who is a nationalist and what comprises the national in India, this study attempts to theorize the ways in which the idea of a nation and nationalism has relied on a return to the pre-colonial past in order to present answers to questions surrounding the notion of Indianness, what constitutes national identity and how religious identity attaches to these questions. Political possibilities emerge, when specific religio-cultural histories are traced to flesh out the notion of a united, homogenous nation/national identity. As stated earlier, often enough, the assertion of pure religio-cultural essences as constituting national identity is made possible by a return to and recovery of pre-colonial narratives involving events and sites that are sought out as evidence to demonstrate the 'truth' of these pure identities. These identities are then exhibited as attaining feasible political possibilities. Political because the very procedure of return is an endeavor to create an epistemology of everything that revolves around the category of 'national'. And this epistemological project typically extends an Orientalist procedure that invests in the essentializing rigors of selfing and othering. These mutually enabling processes project a political possibility of attaining hegemonic dominance in the socio-political arena, alias, the realm of national politics.

It is within this range of consequential relationships that the Darghas of Karnataka surface as having an inbuilt 'juxstapositionality' viz-a-viz the narratives of purist claim and assertions of pure religio-cultural essence propelling definitions of nationalist and nation. The pre colonial that is accessed by pure identity assertionists is accessed using a discourse of exclusion, in that, it frames identity assertions on the basis of evidence that is sifted and which is fenced in within a pre colonial temporality. The corpus of evidence that assertionists tap prompts the exclusionary protocol upon which their identity is imagined as having 
national imperatives. Therefore, the pre colonial evidence that is presented as the building material for purist self assertions, reveals excluded evidence of a large terrain of hybridities, ambivalent identities and shared sacred spaces. One such terrain is the shared spaces of the Darghas of Karnataka. Within these spaces, land, practices, pilgrimages, devotion and deities unfold within a resourceful generosity that defies the vulgar binaries of purist selfing and othering.

One of the most disputed sacred sites in Karnataka's recent history is that of Baba Budan Giri Swami Dattatreya Peeta, in Chikamagalur district. It has attained the dubious status of a disputed site in recent years due to the ideological utterances of the Hindu right that persist in presenting the site as stolen from Hindus by Muslim rulers. It has been reconstructed in the popular imagination as belonging originally to worshippers of the Hindu deity Dattatreya. This claim attempts to erase the history of Baba Budan Swamy Dattatreya Peeta as it has been known for centuries in Chikmagalur district of Karnataka.

Atop a scenic hill range the khanqah or hospice of Dada Hayath Qalander is a sacred site of pilgrimage. The devotees of both Hindu and Muslim religions have regularly offered prayers at both the cave that Baba Budan is known to have meditated in and broken coconuts and conducted pujas to Swami Dattatreya at the temple that exists alongside the cave. The Hindu right wing in India commonly known as the Sangh Parivar has disrupted this coexistence of Hindu-Muslim religious practices consistently, leading to the communalization of the site. One of the performatives that has brought about a believing community of Hindus in the nearby town of Chikmagalur at the base of the Baba Budan hills is the festival of Dattatreya Jayanti or the birthday of Swami Dattatreya that has never been celebrated by Hindus before the Sangh Parivar took to communalizing the region.

Sudha Sitaraman in her working paper on the Baba Budan Giri Dargha ${ }^{2}$ attributes the significance of the site for both Muslims and Hindus to the fact that "Dada Hayath Qalandar, the founder of the Qalandar order is believed to be one of the three-and-half Qalandar masters who visited South Asia, the other two being Lal Shahbaz Qalandar of Sehwan (Sind) and Bu Ali Shah Qalandar of Panipat (Harayana)." Sitaraman goes on to state that:

Muslims as well as many nonMuslims participate in some form of saint worship, a model that is centered on the belief that the divine blessing of the saint does not disappear after

2 Sitaraman, Sudha. "Conflict over Worship: A Study of the Shree Guru Dattatreya Baba Budan Giri Dargha in South India." (C) 2010, Copyright Reserved. The Institute for Social and Economic Change, Bangalore. Working Paper 239. ISBN 81-7791-195-3. http:// www.isec.ac.in/WP\%20239\%20-\%20\%20Sudha\%20 Sitharaman.pdf 
death but is transferred to the chillah/ dargah and the living descendants of the silsila (spiritual pedigree). For Muslims saint worship is an integral part of their orthodoxy, which holds that the barakat (spiritual blessing) of the saint was transferred to his living descendants and is concentrated in certain individuals, the custodians of the shrines, who are also the representatives of the saint on earth, the sajjadah nashins. ${ }^{3}$

She goes on to describe:

The practice of wearing amulets and curing diseases remain at the center of ritual and religious mediations of many Darghas. The power of their spirituality, known as barakat, and their ardent devotion to God it is believed gave Sufi saints powers to perform miracles. Karamat, which refers to the miracles displayed by the "friends of God'or 'auliya' made up an integral part of the faith practices of Sufis. Sitaraman notes that devotees who visit the Dargha often offer supplications and prayers with regard to "the curing of diseases, levitation, and prayer for rain, bountiful crops, controlling of demons, and the presence of the saint in more than one place simultaneously". ${ }^{4}$

Sitaraman reports in her study of the Baba Budan Giri Dargha, that on any ordinary day, pilgrims and devotees visiting the Dargha routinely walk to the natural spring at Manikyadhara. The ritualistic bathing involves discarding

3 Sitaraman, p.6

4 Ibid an item of their clothing in a symbolic gesture of getting rid of the unclean and impure and retaining the pure within the self. This done, they enter the shrine to offer prayers or to do the puja depending on whether one is Muslim or Hindu. The supplicants make an offering of coins, incense sticks, chador, and food to the deity. These offerings usually follow the fulfillment of a vow taken by the devotee. ${ }^{5}$

The celebration of Urs at Baba Budan Giri Dargha has representatives belonging to the Qalandari and fuqara of four orders who hold Dada Hayat in high esteem. On the morning of the first day of Urs fuqara from these orders parade through the streets of Chikmagalur with the green flag that is to be hoisted at the Dargha. They walk 32 kilometeres up to the point of Dada Hayat's hospice where the sajjadah nashin formally heads the procession leading the gathering to the shrine's entrance to hoist the flag. Three flags are hoisted- one, at the hospice, a second at the mazar of Sayyed Shah Jamaluddin Maghribi and a third at the entrance of the cave. This done du'a or prayer is offered. A procession is then taken bare foot to Attigunde, a village, a little more than eight kilometers away, where a sacred pot of sandalwood paste wrapped in a green cloth is carried by a mendicant on his head, while another accompanies him, holding a richly embroidered protective umbrella 
to shade him. The procession steps out of the house, with the mendicants singing and playing their tambourines, and then returns to the cave of Dada Hayath. As the procession reaches the hospice, the gathered devotees and pilgrims comprising Muslims and Hindus, reach out to touch the pot of sandalwood paste. Within the cave the sajjadah nashin washes the sacred seats and graves. The sajjadah nashin recites the opening prayer and invokes blessings of the saint Dada Hayath and his disciples. He and the mendicants smear sandalwood paste on the new sheets to be used as a covering. This is the 'sandal ceremony'. ${ }^{6}$

After this ceremony, devotees and pilgrims are allowed entrance into the cave where the saint meditated. They first approach the 'chillah' (a spiritual practice including penance and solitude within a solitary cell) of Dada Hayath, have a glimpse of the portal and the lamps that he used as well as of a silver replica of his slippers, and are then given holy water to drink by the sajjadah nashin or his representative. Thereafter, Sitaraman notes, "they place flowers and sprinkle rose water on the tombs of Dada Hayath's disciples (Jan Pak Shahid, Malik Tijar Faruqi, Malik Wazir Isfahani and Abu Turab Shirazi) and the seat of Mama Jigni (who was a disciple of Dada Hayat, and who is worshipped as Anusuya by

6 Sudha Sitaraman records the rituals that accompany Urs celebrations in great detail in her working paper cited earlier.
Hindu devotees) while the mujawar recites the fatiha. Pilgrims collect mud in little packets from a recess near Mama Jigni's chillah. This is believed to possess special medicinal properties. When they emerge from the cave they break one or more coconuts on a black stone at the entrance to the shrine. ${ }^{7}$ This concludes the ritual ceremonies of the first day of Urs. For the rest of the day, the mendicants gather at the faqirchowk offering advice and counseling to the pilgrims converging on them. Three days of Urs are celebrated with the next two days seeing a flood of fakirs and mendicants and pilgrims flocking to the hilltop cave and temple seeking blessings and making vows and offerings."

The Hindu devotees who visit the shrine have for centuries worshipped Baba Budan/ Dada Hayat as the avatar of Swami Dattatreya. Represented in the Puranas (the sacred books of Vedic Hindus) as having three faces, namely those of Brahma, Vishnu and Siva, Dattatreya is known to have been born to Anusuya as the incarnation of the Hindu triune God in one body. Four dogs sit beside him signifying the Vedas. He is also worshipped as the presiding deity for the undertaking of yoga. The saint disciple of Baba Budan, Mama Jigni whose tomb is also held sacred and resides in the cave of meditation is worshipped by Hindus as

7 Sitaraman, p.9

8 Ibid 
the mother of Datttreya, Anusuya. ${ }^{9}$

However, all these elaborate shared spiritual and ritual practices have been increasingly disrupted since 1991 and the infamous fall of the Babri Masjid. ${ }^{10}$ The Datta Peetha Samvardhana Samiti a Hindu right wing association has successfully demanded the flying of the Hindu saffron flag (Bhagavadhwaja) at the flag post of the sacred site alongside the green flag that announces a Dargha at the 'Dattatreya temple', accompanied by the singing of bhajans or devotional hymns. Sitaraman documents that in response to the demand, "the District Commissioner, citing the earlier court order had "requested" that no new rituals be introduced. However, these demands have become tradition now."

In 1997, five Rath Yatras, a Hindu form of pilgrimage hitherto unheard of were undertaken by the Datta Peetha Samvardhana Samiti. The objective of the yatras was the demolition of Dada Hayat's chilla. The Samiti was selling the narrative that the idol of Swami Datta Treya lay buried under the chilla ever since the construction of the Dargha by the Muslims who had razed the original construction to the ground: a Dattatreya temple. A subsequent

9 https://www.frontline.in/the-nation/a-battlefrontin-the-south/article10074157.ece. The Nation. BabaBudangiri: A Battlefront in the South.Vikhar Ahmad Sayeed. Print Edition: March 02, 2018.

10 https://www.thehindu.com/opinion/op-ed/whenthe-last-dome-fell-a-first-person-account-of-the-babrimasjid-demolition/article21273367.ece "When the last dome fell: a first-person account of the Babri Masjid demolition." Sajeda Momin. December 06,2017 11:55 IST.

11 Sitaraman, p.14 demand was made for the Hindu worship practices to be introduced and a Hindu priest be given charge of the ceremonies rather than the present practice of a mujawar conducting the worship at the site says Sitaraman. Today, the Samiti has successfully instituted three annual festivities, which were not in existence since pre colonial times. One is the Datta Mala Abhinaya, Shobha Yatre and Anasuya Yatre that has been set in place to recognize the Hindu origins of the space. The word Dargha was seen as detrimental to the identity of the devotees who were positioned as truth bearers of Indian identity. The recasting of roadways and maps followed with disputes over the naming of the Dargha. The recent demand has been that the District administration must permit the Samiti to receive a half of the proceeds that flows in during the Urs of Dada Hayat since they claim the site was originally a temple and therefore partially belongs to the Hindus of the region. ${ }^{12}$

Sitaraman records that in the Hinduization of this sacred space: “... the district administration has also played a proactive role in converting the mosque into an office and proposes to remodel the tombs on either side of the pathway to the cave into a garden. The khanqah's langarkhana, faqirchowk, chillahkhana and dhunna have all been razed to the ground by the district administration. The role these spaces played in the daily and annual rituals has, therefore, been completely altered. As the khanqah has been razed to the ground,

12 Sitaraman, p.14 
the loban that was being traditionally carried to the shrine is now being carried from the makeshift room adjacent to the courtyard; as the administrative powers now rest with the Committee, the victuals that were distributed as part of the daily ritual have now been abandoned; the chador on the chillah of Dada Hayath has been permanently removed; the flag-post that kept the flag (nishani) stands empty."13

In keeping with the narrative of pure religio-cultural identities as enabling a pure essential Hindu Indian identity, the Samiti members and the ideologues of the Hindu right ascribed pure origins on to erstwhile shared sacred religio-cultural sites. Pure identities were fleshed out in Hindu deities, idols and devotees.

The diachronic unfolding of Indian history tracing the emergence of people from primitive understandings of themselves to the more civilizational/ modern understanding of identity as being the effect of the nation as constructed for purposes of decolonization, presents a contrived narrative. It produces spheres of differential reality due to the ensign-like marking of a center that a community then rallies around. Within this dynamic, religio-cultural essences are crafted and circulated in an attempt to establish fixed, impermeable national identities that are imaged and represented as authentic and original. Any community or site or experience that renders this identity porous is perceived as threatening and disruptive and to be checkmated. This is the dynamic that we see at work at the site of Baba Budan Giri. A dynamic that has ruptured the shared terrain of inter culturality and inter religiosity to establish in its stead a purist rendition of what India comprises. This idea of India as a nation that was originally Hindu and must be revoked as such mobilizes communities like the Samiti has to claim spaces, deities and worship protocols by way of a return to a Vedic sacred narrative. In other words, the historicization of pure Indian origins and the assertion of Hindu Vedic origins as the core of being and becoming Indian is performed into being. The performative utterances in the form of 'yatres' and 'jayantis', flag hoistings and sloganeering brings a community into consensus. The recovery of Vedic Hindu evidence to frame the idea of India and Indianness exerts certain inclusions and exclusions that are driven by the Hindu Right's desire to harness the nation for itself. This can be done only when it is claimed as already always being part of its origins, and this claim is demonstrated by utterances that provide tangible evidence.

This is contradictorily seen when a closer study of Darghas extant as pre colonial sites of worship and pilgrimage reveal a decided lack of pure identity. Instead, there is a definite give and take of religious myths, practices and spaces and a 'coevalness' that defies the Hindu nationalist assertions of pure religious 
identities.

The sacred site of the Yellamma temple at Saundatti too has a long history of gracious exchange between the Muslim and Hindu communities who have celebrated Urs at the Dargha and performed the Yellamma festivities side by side since pre colonial times. Yoginder Sikand in his book Sacred

\section{Spaces: Exploring Traditions of}

Shared Faith in India ${ }^{14}$ in travelogue

style presents the case of the Elamma community of Saudatti.

In Saudatti, in Northern Karnataka, the temple belonging to Elamma, a lower caste goddess is today being post scribed as having Brahmin lineage. The deity who has for centuries been worshipped by the Dalits of Karnataka because of the myth that accompanies her reincarnation as a woman with the head of a Dalit, Matangi, and the body of a Brahmin, now is being vehemently denied her Dalit pedigree. A little must be said in this regard to process the method of erasure that is mobilized by the heresies of dominant discourses that seek to gain hegemonic dominance.

Yoginder Sikand, in his revelatory book, records the Brahminization of narratives from as early as the ninth century in Karnataka. He states that by the ninth century a Brahminical revival of sorts led to a massive genocide of Jain monks and the destruction of Jain temples, and more often the appropriation of Jain spaces of worship. The Elamma temple at Suandatti many local people say was one such appropriation of Jain space by the rising Brahminization of regions. Sikand records that the Gazetteer of India documents that the cult of Elamma is defined by its lower caste devotees and is a blend of Mahayana Buddhist and Nath Shaivite traditions, both of which began as anti- Brahminical movements. ${ }^{15} \mathrm{He}$ also cites Elmore, one of the few scholars to have studied the Elamma religious space, and who identifies the origins of the goddess in the original form of 'Mathamma', the patron goddess of the Madiga Dalits, who have been noted as the lowest of the lower castes in the local hierarchy of castes. $^{16}$

Sikand records a booklet written by a Brahmin scholar who claimed that "Elamma is a form of Shakti Herself". 'The Goddess appeared in the form of Renuka in the sat yug, the age of truth; as Draupadi, the wife of the five Pandavas in the dvapar or second era; as Janaki in the tretha , the third era; and in this evil age of kali yug, she has assumed the form of Elamma to redeem the world'. ${ }^{17}$ He notes the fact that Elammma of Saudatti was attracting increasing numbers of pilgrims spurred the Brahmin community into taking control of the temple, its proceedings

15 Sikand. p. 72.

16 Ibid

17 Ibid 
and the goddess. Just as the erasure of the Dalit origins of Elamma has been afoot to reinstate the Goddess to her rightful pedigree as Brahmin deity, so also, Elamma's Sufi connections are relatively unknown.

Almost anyone who knows of Elamma Devi thinks of Saudatti as a Hindu sacred space, but not many know of her links to a Sufi saint in Saudatti, Baba Bhaure Shah, a well noted saint within the village of Saudatti. Sikand documents the locals question to him: How can you expect to get the full blessings of the sister if you don't meet the brother? ${ }^{18}$ According to the local legend, Elamma was suffering from leprosy when Baba pitied her took her as his disciple, cured her miraculously and gave her a special spot for her to meditate on the hill. And this is the spot upon which Elamma's temple stands. This community therefore on the day of the full moon, when Elamma is supposed to have lost her husband, special food is cooked by her Hindu followers and sent across to Baba's shrine. The local people stated that earlier those who travelled to the Elamma temple they visited Baba's tomb as well. But with the recasting of Elamma into a Brahmin deity, this practice has stopped. ${ }^{19}$ The erasure of tradition and rituals of worship in Saundatti are a classic case of the deliberate forgetting that is imposed by

18 Sikand. Sacred Spaces. p.73 19 Sikand. Sacred Spaces. p.74
Brahminization and Sanskritization of sacred spaces.

Considering the ways in which the idea of the nation and national identity have been crafted we find that the identity of a nation is constituted walking backwards, that is to say historically, so that it follows that the making of a nation is an epistemological procedure. Making the nation known to its consumers therefore extends an Orientalist discursive practice that is ironically what colonialism survived on and heavily invested in. The nation is thus involved in essentializing processes of selfing and othering, the very same operative that the decolonization process contested and apparently ousted, only to be reinstated for other masters to be served.

Across the length and breadth of Karnataka communities from Hindu and Muslim religio-cultural spaces have crossed over to enrich religio cultural identity formulations. The case of the founder of the Bahmani dynasty Sultan Hasan Gangoh is another such. ${ }^{20}$

Sikand documents that he is said to have been blessed by a Brahmin priest who saw the orphaned child Hasan asleep under the protection of a hooded cobra that stood over him guarding him from the scorching sun. The Brahmin then prophesied that he would be a ruler of a kingdom. When this prophecy came true many years later, Sultan Hasan as King of Gulbarga

20 Sikand.p.82-83 
in north Karnataka, included the name Bahmani, a distortion of 'brahmin' in his dynastic title, to demonstrate his thankfulness for the blessing. When his son Sultan Ahmed ascended the throne after him he is recorded to have brought rain to his people by merely lifting his hands to God in supplication when the rains had failed in that part of Karnataka. He is thereafter known as 'Wali' (dear to the Lord) by his Muslim subjects and is identified by the Hindu and Lingayat subjects of his kingdom as the incarnation of Allama Prabhu the twelfth century, Shaivite Lingayat leader and poet-saint, renowned for his anti caste-class-patriarchal songs and discourses across India. His Dargha is even today a pilgrimage site for Muslim, Lingayat and Hindu devotees.

Sadly, the bond between Muslim, Hindu and Lingayats has been systematically obliterated as the Lingayats of the region are more and more appropriated into Hinduism and the Muslim Sultan's Dargha has been now converted into a Wodeyar caste temple. But even so, during Urs a Muslim is asked to read the 'fatiha' (opening prayer) before the performance of the Hindu 'puja's (worship of the deity) at the temple. The minarets still stand atop the Hinduized temple that was once a dargha, preserving the history of a coevalness between these communities around these religiocultural sites. ${ }^{21}$

21 Sikand. p.83
The three sites detailed above are some of several such sites that predate the birth of the Indian nation. These sites and practices speak for integrated, fluid religio-cultural identities that have been resilient in several parts of India since pre colonial times, Karnataka being an example of the same.

I cut to an incisive analysis of how events and spaces are historicized either as memory or as forgetting by Shahid Amin. Amin, talking about the Chauri Chaura event in the making of the Indian nation state suggests that the peasant rebellion was at its core a celebration of Gandhian nationalism albeit a violent nationalism..$^{22}$ The curiosity of this case is relevant here for us to understand the fraught nature of what is performed as nationalist/ nationalism. Amin brings out the contradictions within nationalisms in India during the time of Gandhi noting that while Gandhi's call was for non violent defiance of the Raj that was possible with a cultivation and deployment of spiritual performatives such as sathyagraha or non violent civil disobedience, the peasants who were instrumental in making Gandhi into a 'mahatma' sent up a triumphant cry of 'Mahatma Gandhi ki Jai' after the gutting of the Chauri Chaura police station, and the slaughter of the policemen in the police chowki.

The question that surfaces from

22 Amin, Shahid. Event, Metaphor, Memory: Chauri Chaura 1922-1992. University of California Press. Berkley, Los Angeles. Oxford University Press. 1995. 
Amin reading of this event is as regards the way in which this violent protest is turned into an incident that is remembered only so as to forget it. Since the incident did not coincide with the master narrative of a decolonization endeavor that was radically non violent and spiritual, but was on the other hand, a violent, revenging of the people on the British use of force at the Jalianwala Bagh massacre, it was treated as an aberration. However, this very 'aberration' reveals something of the nature of nationalism. That in fact, it is a restless force that will not be contained within a singular, structured performative.

The Chauri Chaura incident of 1922 is a case in point that brought peasants together to perform the idea of nation that had taken shape in the minds of the community of that region. That it evacuated the kind of nationalism that Gandhi was calling for - that of civil disobedience- uncovers the plural fissures through which a community may stain the homogenizing fabric of that which is presented as an Indian nationalism. ${ }^{23}$

In a contradictory parallel, the pre colonial temporality that is accessed in order to develop the idea of a homogenous Hindu Indian pure identity is ruptured and rendered false by the multiple fissures through which grace, generosity and sharing overflow the homogenizing, essentializing fabric of purist assertions of Indian ness that nurture Vedic abstractions of nationalist practice, identity and what constitutes Indian ness.[]

23 Amin, Shaid. "The Crime of Chauri Chaura" in Event, Metaphor, Memory: Chauri Chaura 1922-1992. University of California Press. Berkley, Los Angeles. Oxford University Press. 1995. 